Hayward, A. C., Forsyth, W. G. C. \& Roberts J. B. (1959). J. gen. Microbiol. 20, 510-518

\title{
Synthesis and Breakdown of Poly- $\beta$-Hydroxybutyric Acid by Bacteria
}

\author{
By A. C. HAYWARD, W. G. C. FORSYTH AND J. B. ROBERTS \\ Colonial Microbiological Research Institute, Port of Spain, Trinidad, \\ West Indies
}

SUMMARY: The synthesis and breakdown of poly- $\beta$-hydroxybutyric acid in growing cultures of selected strains of Rhizobium, Spirillum and Pseudomonas are described. The occurrence of the polymer in root nodules of tropical and temperate leguminous plants is reported.

The occurrence of poly- $\beta$-hydroxybutyric acid in the genus Bacillus was reported by Lemoigne, Delaporte \& Croson (1944), who were able to correlate the presence of prominent refractile granules in the cells with the isolation of a wax-like, chloroform-soluble, ether-insoluble polymer from the large-celled bacilli, Bacillus megaterium, B. cereus, B. mycoides and B. anthracis. Williamson \& Wilkinson (1958) extracted the inclusions with an alkaline solution of sodium hypochlorite and proved that poly- $\beta$-hydroxybutyric acid was their major constituent. Lemoigne \& Girard (1943) demonstrated the same polymer in Azotobacter chroococcum. Recently Forsyth, Hayward \& Roberts (1958) recorded the presence of poly- $\beta$-hydroxybutyric acid in $A$. vinelandii and A. agilis and also in Rhizobium, certain pseudomonads and Chromobacterium, groups in which the presence of the polymer had not previously been suspected.

A considerable amount of work has been carried out on the chemical composition of the root nodules of leguminous plants and of bacteria isolated from them, yet there has been no positive chemical identification of the wax-like sudanophilic material known to occur in Rhizobium (Lewis, 1938). Moller (1892, cited by Lewis, 1938) studied the effect of various solvents on the refractile granular inclusions of Rhizobium and showed that they were insoluble in ether, but soluble in chloroform. He concluded that the waxy substance corresponded most nearly to cholesterol, which was also the conclusion of Muller \& Stapp (1925, cited by Lewis, 1938) from a chemical analysis of bacteroids. Hopkins, Peterson \& Fred (1929) extracted dried Rhizobium meliloti 100 with chloroform and ether, and showed that different samples of this organism contained between $\mathbf{1 0 . 2}$ and $\mathbf{2 1} \cdot \mathbf{7} \%$ of the dry weight as a chloroform-soluble fat-like substance, which was isolated as a brittle mass having a melting point of $172-173^{\circ}$ (Hopkins \& Peterson, 1930).

In Spirillum several types of granule have been recognized. Volutin and 'fat' were described by Lewis (1940), though Williams \& Rittenberg (1957) were unable to confirm that the 'fat' granules were sudanophilic. King \& Beams (1942) subjected Spirillum volutans to ultracentrifugation and succeeded in displacing all the visible granules into the centrifugal region. They thus con- 
cluded that the granules, of which there were at least two types in the cell, were heavier than the protoplasm surrounding them. As only a minority of the granules refractory to staining with iron hematoxylin reduced osmic acid they concluded that these granules were not fat. With Bacillus megaterium, Williamson \& Wilkinson (1958) provided convincing evidence that volutin and the inclusions containing poly- $\beta$-hydroxybutyric acid can be differentiated by staining techniques and have a separate identity. The evidence in the case of Spirillum is less conclusive.

The present study, and that reported earlier (Forsyth et al. 1958), were undertaken because it was suspected that poly- $\beta$-hydroxybutyric acid is more widely distributed in bacteria than previously realized, and may occur in the bacterial cell in massive concentrations when the organisms are grown under appropriate conditions. The effect of substrate concentration on polymer yield has been investigated.

\section{METHODS}

Organisms. The majority of bacteria used in this study were obtained from Miss M. B. Morris, Curator, Hankey Culture Collection at this Institute; the cultures of Pseudomonas solanacearum were freshly isolated from banana plants with 'Moko' disease and from wilted tomato plants. Cultures of Rhizobium spp. from the temperate zone were obtained through the courtesy of Dr G. Bond, Botany Department, University of Glasgow. Cultures of Spirillum were obtained from the National Collection of Industrial Bacteria, Teddington, Middlesex, as follows: Spirillum serpens, NCIB 8658, and three large-celled, unidentified, spiral bacteria numbered I, II and III, isolated by micromanipulation of single cells from Hampton sewage. Several spiral bacteria were isolated by us from calcium lactate enrichment cultures as described by Williams \& Rittenberg (1957).

An organism (strain B175) which produces a phenazine pigment, was also used and was typical of many similar strains isolated from Trinidad soils.

Methods of cultivation. A New Brunswick type rotary shaking machine was used at either 200 or $300 \mathrm{rev} . / \mathrm{min}$. The organisms were grown in $250 \mathrm{ml}$. conical flasks containing either 50 or $100 \mathrm{ml}$. medium. The temperature of the room housing the shaker varied between $26^{\circ}$ and $29^{\circ}$.

For cultivation of the pseudomonads use was made of the salts solutions (i) and (ii) described by Powell (1958). Concentrated glucose solutions in distilled water were sterilized separately by autoclaving, and solutions of sodium hydroxybutyrate (British Drug Houses Ltd., lab. reagent) by Seitz filtration; they were then added with sterile precautions to the basal salts medium.

Cultures of Rhizobium were grown in a modification of Allison's medium prepared as described by Wilson \& Knight (1952). D-Mannitol (20 g./l.), DLasparagine ( $1 \mathrm{~g} . / 1$.) and Difco Yeast Extract (1 g./l.) were added to the solution of salts, together with $1 \mathrm{ml} . / 1$. of a $0.9 \%(\mathrm{w} / \mathrm{v})$ solution of ferric chloride. Most but not all rhizobia grew well in this medium.

Spirillum serpens 8658 was grown in Allison's medium as described above, but with $2 \%(\mathrm{w} / \mathrm{v})$ lactic acid instead of $\mathrm{D}$-mannitol. 


\section{A. C. Hayward, W. G. C. Forsyth and J. B. Roberts}

Staining methods. Lipid inclusions in smears and crushed root nodules were stained with an ethanolic solution of Sudan Black B (G.T. Gurr Ltd., London) according to the method of Burdon (1946).

Dry-reight determinations and polymer extraction. Whole cultures were centrifuged and usually washed once in distilled water before drying overnight at $105^{\circ}$. Dried deposits were then scraped out into a weighing bottle, weighed, dried again for several hours, weighed again, pulverized, extracted twice or three times with chloroform and the polymer precipitated by dilution with ether (Forsyth et al. 1958). Poly- $\beta$-hydroxybutyric acid precipitates were dried at $105^{\circ}$ overnight before weighing.

Organic matter and keto acids. Keto acids were determined in the supernatant liquors by the method of Cavallini \& Frontali (1954), and organic matter by the method of Johnson (1949). Melting points were taken on a Kofler block, of the temperature at which melting began. Melting points were uncorrected.

\section{RESULTS}

\section{Rhizobium}

Washed and dried root nodules were pulverized and extracted with chloroform whenever they were available in sufficient quantity for a quantitative examination; otherwise nodules were crushed on to a slide and stained with Sudan Black B. Results are summarized in Table 1. Most isolates of Rhizobium produced a

Table 1. Occurrence of poly- $\beta$-hydroxybutyric acid in root nodules of leguminous plants

Source of root nodules
Immortel (Erythrina poeppigiana)
String bean (Vigna unguiculata
sesquipedalis)
Canavalia maritima
Mimosa pudica

\begin{tabular}{cccc}
$\begin{array}{c}\text { Wt. of dried } \\
\text { nodules } \\
\text { (mg.) }\end{array}$ & $\begin{array}{c}\text { Wt. of isolated } \\
\text { polymer } \\
\text { (mg.) }\end{array}$ & $\begin{array}{c}\% \\
\text { dry wt. }\end{array}$ & $\begin{array}{c}\text { M.P. } \\
\left({ }^{\circ} \text { C. }\right)\end{array}$ \\
$\begin{array}{c}\text { *(i) } 2830 \\
\text { (ii) } 2733\end{array}$ & 229 & $8 \cdot 1$ & 170 \\
1896 & 143 & $5 \cdot 2$ & N.M. \\
& $137 \cdot 5$ & $7 \cdot 3$ & 172 \\
2022 & & & \\
*(i) 900 & 239 & $11 \cdot 8$ & 167 \\
(ii) 332 & 54 & $6 \cdot 0$ & N.M. \\
\hline
\end{tabular}

Flocculent, chloroform soluble, ether insoluble, material was also obtained from small samples of the root nodules of lupin (Lupinus), kudzu (Puereria) and gorse (Ulex). Crushed nodules of bush vetch (Vicia sepum) and Crotalaria, which were not sufficient for extraction, were strongly sudanophilic.

* (i) and (ii) are samples from different localities. N.M. = not measured.

copious polysaccharide capsule on agar or in shake-flask cultures, which invariably made centrifugation difficult. One strain, B 142, from Pueraria was chosen for further study because it produced little or no capsular gum. Duplicate shake flask cultures in Allison's medium were removed at 2-day intervals and the dried organisms from each separately extracted with chloroform. The results (Fig. 1) indicate that massive quantities of poly- $\beta$-hydroxybutyric acid were formed during the growth of strain B 142. Many other rhizobia produced 
comparable yields. Cultures of $\mathrm{B} 142$ also grew vigorously and with production of polymer when the D-mannitol of the basal medium was replaced by glucose, glycerol or sodium hydroxybutyrate.

The following strains of rhizobia obtained from the Botany Department, University of Glasgow, were shown to contain poly- $\beta$-hydroxybutyric acid: Field bean (strain S), Lucerne (strain AH), Trifolium (strains 21, F, 49 R, 101 and 20272), Phaseolus (strain 5B) and Pisum (strain 317). All were grown in Allison's medium on the rotary shaker for periods of 3-14 days.

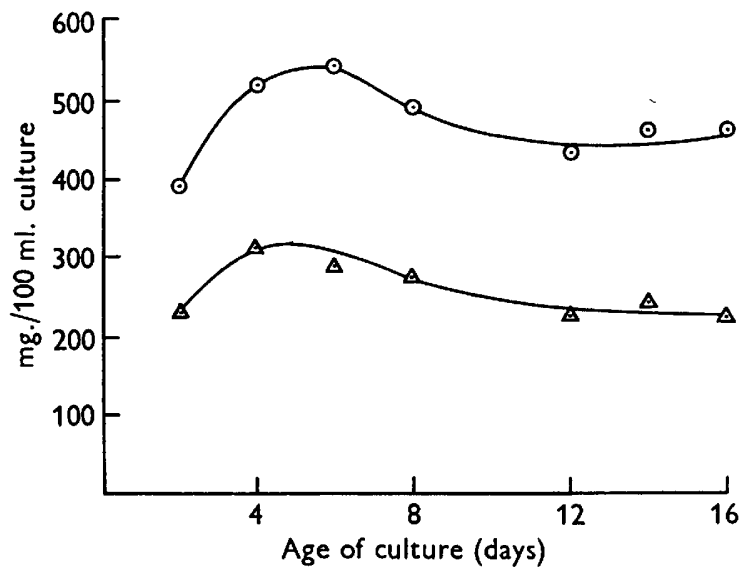

Fig. 1. Poly- $\beta$-hydroxybutyric acid content and dry weight of Rhizobium strain B142 grown in a modification of Allison's medium. $\odot-\odot$, Dry weight of organisms ; $\triangle-\triangle$, weight of poly- $\beta$-hydroxybutyric acid. $100 \mathrm{ml}$. medium $/ 250 \mathrm{ml}$. conical flasks on a rotary shaker at $200 \mathrm{rev} . / \mathrm{min}$. Initial concentration of D-mannitol, $20 \mathrm{~g} . / \mathrm{l}$.

Two cultures of Rhizobium japonicum from soyabean (Glycine) were obtained through the courtesy of Dr P. S. Nutman, Soil Microbiology Department, Rothamsted Experimental Station. Both strain 507, which was ineffective for the fixation of nitrogen, and strain 505 (effective) produced poly- $\beta$-hydroxybutyric acid during growth in a medium containing $\mathrm{L}(+)$ arabinose as major source of carbon.

\section{Spirillum}

The observations of Lewis (1940) led us to suspect that the genus Spirillum Ehrenberg would include organisms capable of synthesizing large quantities of poly- $\beta$-hydroxybutyric acid. The medium used initially contained the following materials (g./l. of distilled water): Oxoid peptone, $5 \cdot 0$; Difco yeast extract, 5.0 ; calcium lactate, 20 . The $\mathrm{pH}$ value was adjusted to $c .7 \cdot 6$ with $40 \%(\mathrm{w} / \mathrm{v})$ $\mathrm{NaOH}$. Heavily inoculated conical flasks of medium were then grown on a reciprocating shaker. After incubation for 16-22 hr. the polymer was extracted. The cultures of Spirillum serpens and strains I, II and III from Hampton sewage were all found to contain between 10 and $20 \%$ poly- $\beta$-hydroxybutyric acid. After incubation for $40-60 \mathrm{hr}$. each culture contained very much less of the polymer; in two cultures none was detectable after $60 \mathrm{hr}$. of incubation. Evidently the polymer was formed in young cultures, in which the spiral 


\section{A. C. Hayrward, W. G. C. Forsyth and J. B. Roberts}

bacteria contained a chain of refractile granules, and rapidly disappeared from old cultures which appeared uniform in smears stained with dilute carbol fuchsin. It became apparent that the calculated \% yields of polymer obtained in these preliminary experiments with calcium lactate were too low because a heavy inorganic precipitate, presumably calcium carbonate, was present at an early stage of growth.

Spirillum serpens NCIB 8658 grew well in Allison's medium containing lactic acid as major carbon source. The results of a typical experiment are shown in Fig. 2. The concentration of poly- $\beta$-hydroxybutyric acid rose to a maximum of $34.2 \%$ of the dry weight at $38 \mathrm{hr}$. and fell to $7.5 \%$ at $110 \mathrm{hr}$. Similar results were obtained when glycerol or sodium hydroxybutyrate replaced the lactate in the basal medium.

\section{Pseudomonas}

Pseudomonas antimycetica (Thaysen \& Thaysen, 1953) grew heavily in the salts medium supplemented with $2 \%$ lactic acid and produced a maximum of $51.5 \%$ polymer in the dry cell weight.

The rough colony form of Pseudomonas solanacearum grew slowly with synthesis of polymer in the salts medium supplemented with either glycerol or $\beta$-hydroxybutyrate. The appearance of the cells of the smooth colony form of $\boldsymbol{P}$. solanacearum in 'fat' stained smears was very characteristic, the greater part of the cell staining intensively with Sudan Black B. According to Dowson (1949) this plant pathogen does not stain readily by the usual bacteriological methods. In smears stained with dilute carbol fuchsin there was a bipolar effect, which has not previously been associated with the presence of 'fat'.

Non-pigmented Gram-negative rods having an oxidative metabolism of carbohydrates have been isolated in a lactate + salts enrichment medium, and a few of these have proved to contain poly- $\beta$-hydroxybutyric acid. One type isolated twice from river water resembled Vibrio; the others are probably pseudomonads. Green pigmented pseudomonads have so far proved to be devoid of the polymer (Forsyth et al. 1958) but experiments with selective media are continuing.

\section{Strain B 175}

This organism, typical of many similar strains isolated from Trinidad soils, has polar flagella and produces a phenazine pigment (Morris \& Roberts, unpublished). Its classification is not yet settled but it is probably a pseudomonad.

Strain B 175 grew heavily and produced poly- $\beta$-hydroxybutyrate in the salts medium supplemented with glucose, glycerol, lactate, citrate, succinate or $\beta$-hydroxybutyrate as sole source of carbon. The extent of poly- $\beta$-hydroxybutyrate accumulation was conditioned by the initial concentration of glucose (Table 2); in $2 \% \beta$-hydroxybutyrate + salts medium the concentration of polymer fell from a maximum of $51.3 \%$ at $62.5 \mathrm{hr}$. to $3.7 \%$ at $158.5 \mathrm{hr}$. (Fig. 3). The results in Fig. 3 and Table 3 are typical of several experiments in which strain B 175 was grown in $2 \%$ or $0.5 \%$ lactic acid or hydroxybutyrate media. In $2 \%$ lactic acid medium $\alpha$-ketoglutarate accumulated but not at the 
stage of culture when the polymer was rapidly being degraded. There was no accumulation of keto acids at any stage of growth at the lower concentration of lactic acid. Organic matter decreased smoothly. Our results thus support

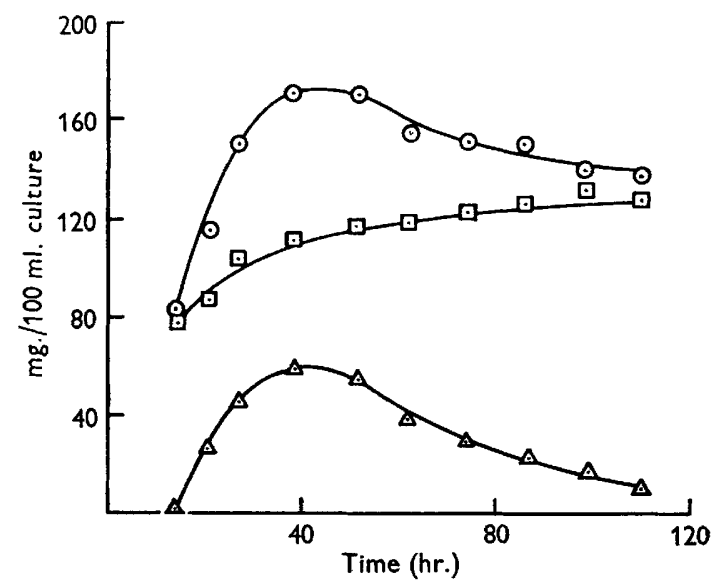

Fig. 2. Poly- $\beta$-hydroxybutyric acid content and dry weight of cells of Spirillum serpens NCIB 8658 grown in a modification of Allison's medium. $\odot-\odot$, Dry weight of organism; $\Delta-\Delta$, weight of poly- $\beta$-hydroxybutyric acid; $\square-\square$, weight of cellsweight of polymer. Inoculum: $1 \mathrm{ml}$./flask of a 5 -day shake-flask culture. Duplicate flasks removed periodically from rotary shaker $(200 \mathrm{rev} . / \mathrm{min}$.). Initial concentration of sodium lactate equiv. to $20 \mathrm{mg}$. lactic acid/ml.; $100 \mathrm{ml}$. medium/250 ml. shake flask.

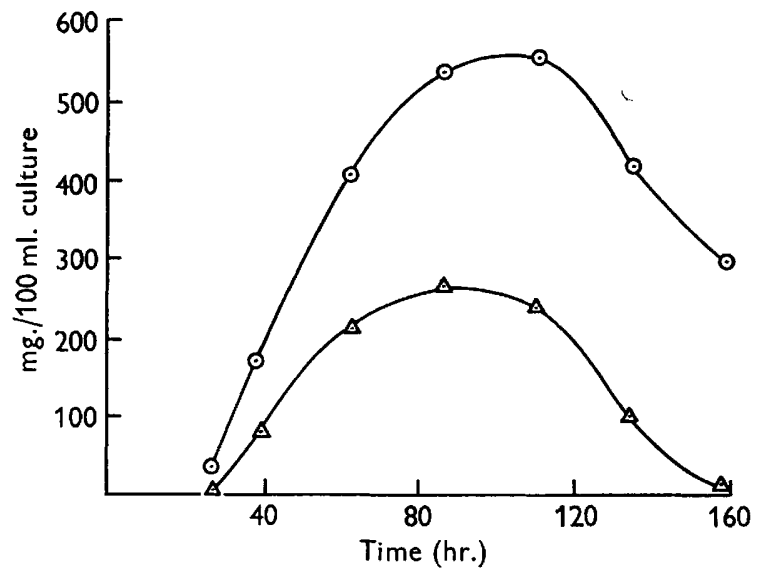

Fig. 3. Poly- $\beta$-hydroxybutyric acid content and dry weight of organism B 175 grown on a sodium hydroxybutyrate + salts medium. $\odot-\odot$, dry weight; $\triangle-\triangle$, weight of poly $-\beta$-hydroxybutyric acid. $100 \mathrm{ml}$. medium $/ 250 \mathrm{ml}$. conical flasks on a rotary shaker (200 rev./min.) Initial concentration of sodium hydroxybutyrate, $20 \mathrm{mg} . / \mathrm{ml}$.

the conclusions of Macrae \& Wilkinson (1958) that under aerobic conditions carbon dioxide and water are the main products of breakdown of the polymer.

There was no evidence in either growing cultures or resting cell experiments that organism B175 could break down finely divided poly- $\beta$-hydroxybutyric acid when this was added extracellularly. 
Table 2. The effect of initial concentration of glucose on the poly- $\beta$-hydroxybutyric acid content of organism $\mathrm{B} 175$

Five ml. of $20 \%$ or $5 \%(w / v)$ sterile glucose solutions were added to $45 \mathrm{ml}$. of basal salts medium. Flasks were incubated on a rotary shaker at $300 \mathrm{rev} . / \mathrm{min}$.

\begin{tabular}{|c|c|c|c|c|c|c|}
\hline \multirow{2}{*}{$\begin{array}{l}\text { Age of culture } \\
\text { (hr.) }\end{array}$} & \multicolumn{6}{|c|}{ Medium contained } \\
\hline & $\begin{array}{r}0.5 \% \\
\text { glucose } \\
\text { mg. c } \\
100 \mathrm{n}\end{array}$ & $\begin{array}{l}\quad 2 \% \\
\text { glucose } \\
\text { y wt./ } \\
\text { llture }\end{array}$ & $\begin{array}{r}0.5 \% \\
\text { glucose } \\
\text { mg. } \\
100 \mathrm{n}\end{array}$ & $\begin{array}{l}2 \% \\
\text { glucose } \\
\text { mer/ } \\
\text { dlture }\end{array}$ & $\begin{array}{l}0.5 \% \\
\text { glucose } \\
\% \text { pol } \\
\text { dry }\end{array}$ & $\begin{array}{l}\mathbf{2} \% \\
\text { glucose } \\
\text { r/cell } \\
\text { ght }\end{array}$ \\
\hline 23 & 203 & 108 & $5 \cdot 0$ & Trace & $\mathbf{2} \cdot \mathbf{5}$ & $<1$ \\
\hline 46 & 172 & 509 & Trace & 162 & $<1$ & $31 \cdot 7$ \\
\hline 92 & 126 & 531 & 0 & 85 & $\mathbf{0}$ & $16 \cdot 0$ \\
\hline
\end{tabular}

Table 3. $\mathrm{pH}$ value, keto acid, and residual organic matter content of supernatant liquors of cultures of organism $\mathrm{B} 175$ grown in a sodium hydroxybutyrate + salts medium

\begin{tabular}{|c|c|c|c|}
\hline $\begin{array}{l}\text { Time } \\
\text { (hr.) }\end{array}$ & $\underset{\text { value }}{\mathrm{pH}}$ & $\begin{array}{c}\text { Organic } \\
\text { matter } \\
(\%)\end{array}$ & $\begin{array}{l}\text { Ketoglutarate } \\
\quad(\mu \mathrm{g} . / \mathrm{ml} .)\end{array}$ \\
\hline $\mathbf{0}$ & c. $7 \cdot 0$ & 100 & 0 \\
\hline $27 \cdot 0$ & $7 \cdot 2$ & 90 & $\mathbf{0}$ \\
\hline $38 \cdot 5$ & $7 \cdot 7$ & 83 & $\mathbf{0}$ \\
\hline $62 \cdot 5$ & $8 \cdot 4$ & 80 & 2 \\
\hline $86 \cdot 5$ & $8 \cdot 3$ & 43 & $7 \cdot 5$ \\
\hline $110 \cdot 5$ & $8 \cdot 3$ & 25 & Trace \\
\hline $134 \cdot 5$ & $8 \cdot 4$ & 20 & 0 \\
\hline 158.5 & $8 \cdot 3$ & 10 & $\mathbf{0}$ \\
\hline
\end{tabular}

\section{DISCUSSION}

There are many descriptions in the literature of sudanophilic inclusions which resist staining with aniline dyes and which may well be deposits of poly- $\beta$ hydroxybutyric acid. Lewis, for example, wrote a series of papers on the cytology and life cycles of Bacillus mycoides (1934), Azotobacter (1937), Rhizobium (1938) and Spirillum (1940), and in each case described inclusions with these characteristic properties. Information is required on the identity of certain opaque structures seen in ultra-thin sections of bacteria under the electron-microscope, which it seems probable may be identical with deposits of poly- $\beta$-hydroxybutyric acid. Hashimoto \& Naylor (1958) described such inclusions in B. cereus and Carr (1958) in Azotobacter agilis. The electronmicrographs of thin sections of Rhodospirillum rubrum prepared by Vatter \& Wolfe (1958) show large spherical vacuoles which they described as corresponding to areas in whole cells which stained with Sudan Black B. Duchow \& Douglas (1949) described refractile globules in the photosynthetic organism Rhodomicrobium vannielii which stained with Sudan Black B and were assumed to be fat. Grula \& Hartsell (1954) studied the intracellular structure of the stalked bacterium Caulobacter vibrioides; intensely sudanophilic 'fat' vacuoles were described. In view of the similarity of these descriptions to those of structures 
in bacteria which are now known to contain poly- $\beta$-hydroxybutyric acid, reinvestigation of the possibility that they do contain this substance is required.

Umezu (1940) described the occurrence of a chloroform-soluble white amorphous substance, melting at $169^{\circ}-172^{\circ}$, which constituted $0.54 \%$ of the dried glanders organism, Malleomyces mallei. Worley \& Young (1945) subjected several strains of this pathogen to fat-staining techniques; Sudan Black B was particularly effective for the staining of 'lipid' granules which failed to stain readily with the usual aniline dyes. It seems probable that this strictly parasitic organism contains deposits of poly- $\beta$-hydroxybutyric acid.

Although solid poly- $\beta$-hydroxybutyric acid isolated from bacteria does not stain with Sudan Black B (Williamson \& Wilkinson, 1958), we have noted that when dissolved in chloroform and applied to defatted filter-paper the polymer deposited in the paper readily takes up the fat stain. Under the same conditions we have found no reduction of the polymer by a $1 \%$ solution of osmium tetroxide which apparently only oxidizes unsaturated fats (McClung, 1951, cited by Williams \& Rittenburg, 1957).

Macrae \& Wilkinson (1958) gave reasons for considering that in Bacillus megaterium, poly- $\beta$-hydroxybutyric acid is a storage compound. The fact that the polymer occurs in root nodules, as well as the synthesis and dissimilation of the material in growing cultures of Rhizobium, Spirillum and Pseudomonas, is in accordance with this suggestion. There have been reports that glycogen also occurs in root nodules as a storage compound (Bergerson, 1955).

The irregular occurrence of poly- $\beta$-hydroxybutyric acid in Pseudomonas suggests that the presence of this substance may be a valuable criterion in the classification of members of the genus, particularly the numerous plant pathogens. A wider study of Pseudomonas is to be undertaken in this laboratory to examine this possibility.

We are grateful to Dr V. C. Quesnel for provision of root nodules and identification of leguminous plants and Mr J. Spence, Department of Agriculture, Trinidad, for assistance in the identification of Pseudomonas solanacearum.

\section{REFERENCES}

Bergerson, F. J. (1955). The cytology of bacteroids from root nodules of subterranean clover (Trifolium subterraneum L.). J. gen. Microbiol. 13, 4.11.

Burdon, K. L. (1946). Fatty material in bacteria and fungi revealed by staining dried, fixed slide preparations. J. Bact. 52, 665 .

CARR, L. B. (1958). Observations on the capsule of Azotobacter agilis. J. Bact. 76, 119.

Cavalini, D. \& Frontali, N. (1954). Quantitative determinations of keto-acid by paper partition chromatography. Biochim. biophys. Acta, 13, 439.

Dowson, W. J. (1949). Manual of Bacterial Plant Diseases. London: Adam and Charles Black.

Duchow, E. \& Douglas, H. C. (1949). Rhodomicrobium vannielii a new photoheterotrophic bacterium. J. Bact. 58, 409.

Forsyth, W. G. C., Hayward, A. C. \& Roberts, J. B. (1958). The occurrence of poly- $\beta$-hydroxybutyric acid in aerobic Gram-negative bacteria. Nature, Lond. 182,800 . 


\section{A. C. Hayrward, W. G. C. Forsyth and J. B. Roberts}

Grula, E. A. \& Hartsell, S. E. (1954). Intracellular structures in Caulobacter vibrioides. J. Bact. 68, 498.

Hashimoto, T. \& Naylor, H. B. (1958). Studies of the fine structure of microorganisms. I. A study of factors influencing the 'explosion phenomenon' in ultrathin sections of bacteria. J. Bact. 75, 640 .

Hopkins, E. W. \& Peterson, W. H. (1930). The nature of the fat-like constituents of the alfalfa root nodule bacteria. J. Bact. $19,9$.

Hopkins, E. W., Peterson, W. H. \& Fred, E. B. (1929). The composition of the cells of certain bacteria with special reference to their carbon and their nitrogen content. J. biol. Chem. 85, 21.

Johnson, M. J. (1949). A rapid micromethod for estimation of non-volatile organic matter. J. biol. Chem. 181, 707.

KInG, R. L. \& BEAMS, H. W. (1942). Ultracentrifugation and cytology of Spirillum volutans. J. Bact. 44, 597 .

Lemoigne, M., Delaponte, B. \& Croson, M. (1944). Contribution à l'étude botanique et biochimique des bactéries du genre Bacillus. 2. Valeur du test des lipides $\beta$-hydroxybutyriques pour la characterisation des espèces. Ann. Inst. Pasteur, 70, 224.

Lemorgne, M. \& Girard, H. (1943). Réserves lipidiques $\beta$-hydroxybutyriques chez Azotobacter chroococcum. C.R. Acad. Sci., Paris, 217, 557.

LEwIS, I. M. (1934). Cell inclusions and endospore formation in Bacillus mycoides. J. Bact. 28, 133.

Lewis, I. M. (1937). Cell inclusions and the life cycle of Azotobacter. J. Bact. 34, 191.

Lewis, I. M. (1938). Cell inclusions and the life cycle of Rhizobia. J. Bact. 35, 573.

LEwIs, I. M. (1940). The genus Spirillum Ehbg. with special reference to cell inclusions and the chromidial theory. J. Bact. 40, 271.

McLung, C. E. (1951). Handbook of Microscopical Technique, 3rd ed. New York: Paul B. Hoeber, Inc.

Macrae, R. M. \& Wirkinson, J. F. (1958). Poly- $\beta$-hydroxybutyrate metabolism in washed suspensions of Bacillus cereus and B. megaterium. J. gen. Microbiol. 19, 210.

Moller, H. (1892). Bemerkungen zu Frank's Mittheilung ueber den Dimorphismus der Wurzelknöllchen der Erbse. Ber. disch. bot. Ges. 10, 242.

Müller, A. \& STapp, C. (1925). Beiträge zur Biologie der Leguminosenknöllchen bakterien mit besonderer Berücksichtigung ihrer Artverschiedenheit. Arb. biol. Abt. (Anst.-Reichsanst.), Berl. 14, 455.

Powell, E. O. (1958). An outline of the pattern of bacterial generation times. J. gen. Microbiol. 18, 382.

Thaysen, A. C. \& Thaysen, I. (1953). Comirin, a new fungistatic antibiotic. Rep. Proc. VI int. Congr. Microbiol., Rome, 1, 321.

UMezU, M. (1940). Rep. Inst. Sci. Res. Manchoukuo, 4, 273. (Chem. Abstr. 1941, 35, 1825.)

VATTER, A. E. \& WoLfe, R. S. (1958). The structure of photosynthetic bacteria. J. Bact. 75, 480.

Williams, M. A. \& Rittenberg, S. C. (1957). A taxonomic study of the genus Spirillum Ehrenberg. Int. Bull. bact. Nomen. Taxon. 7, 49.

Williamson, D. H. \& Wilkinson, J. F. (1958). The isolation and estimation of the poly- $\beta$-hydroxybutyrate inclusions of Bacillus species. J. gen. Microbiol. 19, 198.

Wilson, P. W. \& Knight, S. G. (1952). Experiments in Bacterial Physiology, 3rd ed., p. 52. Minneapolis: Burgess Publishing Co.

Worley, G. \& Young, G. (1945). The glanders organism with reference to its cell inclusions. J. Bact. 49, 97. 